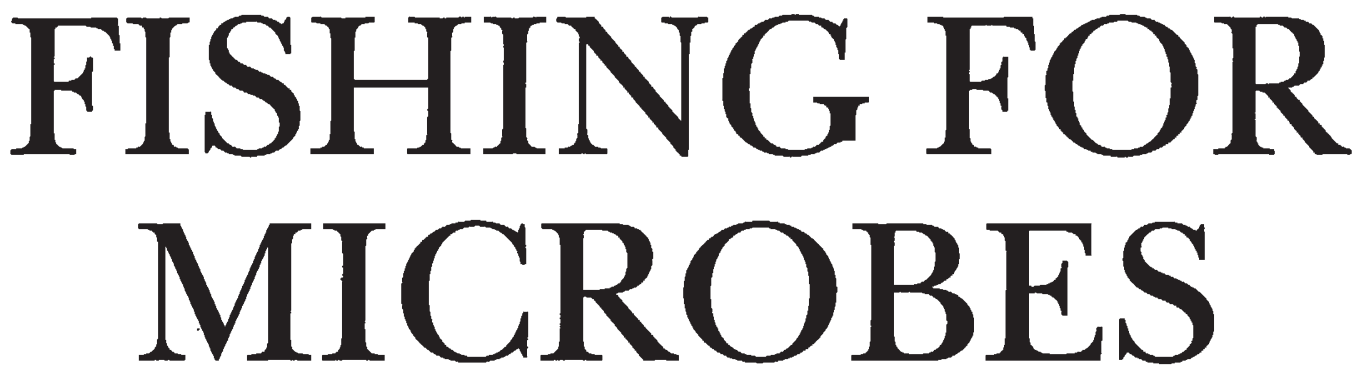

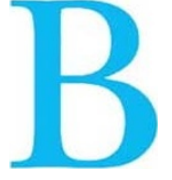

iotechnology is never about one thing. But if it was, that one thing would be people-preferably many people. Those many people should have different skills and outlooks, but a common aim. And they should be in a network-loosely organized enough to let innovation thrive but sufficiently close to share scarce resources and precious information, and close enough to communicate. This, more or less, is how MIRCEN (Microbiological Resources Centers) network operates.

MIRCENs are units associated with academic or governmental institutions whose role it is to encourage and develop in cooperation with other national, regional or international organizations, novel technology development and natural resource management. In 1984, funding from UNESCO (Paris), the UN Environmental Program (UNEP, Nairobi, Kenya) and the International

David Pramer is Associate Vice President for Research, Rutgers University, 337 Hoes Lane, Piscataway, NJ 08854, U.S.

\section{The MIRCEN network}

Key: Biotechnology; Informatics Agriculture HAWAII, US

WATERLOO, CANADA

BELTSVILLE, US

MARYLAND, US

GUATEMALA

PORT OF SPAIN, TRINIDAD AND TOBAGO

PORTO ALEGRE, BRAZIL

TUCUMAN, ARGENTINA

LONDON, UK

LONDON, UK

STOCKHOLM, SWEDEN

BRAUNSCHWEIG, FRG

BUDAPEST, HUNGARY

TOULOUSE,FRANCE

LJUBLJANA, YUGOSLAVIA

CAIRO, EGYPT

DAKAR, SENEGAL

NAIROBI, KENYA

BEIJING, PRC

OSAKA, JAPAN

SAITAMA, JAPAN

BANGKOK, THAILAND

BRISBANE, AUSTRALIA

\section{ResOURCES}

\section{Rhizobium;}

biotechnology and agriculture

agriculture

marine biotechnology; Rhizobium;

biotechnology; Rhizobium;

biotechnology

mycology culture collections;

computer conferencing:

culture collections and patents

culture collections

biotechnology;

informatics and mutagenesis testing;

Voandzeia subterranea

Rhizobium for soybean, legumes

microbial technology

fermentation technology;

culture collection database;
Cell Research Organization (ICRO, Paris) established six pilot MIRCENsin Brazil, Egypt, Guatemala, Kenya, Senegal and Thailand. 'The MIRCEN network now comprises 23 units in 19 countries, each of the units having focussing on agriculture, biotechnology or informatics and is funded by the UN and the U.S. State Department at around $\$ 250-300,000$ per annum.

\section{Microblological}

Each MIRCEN has a central responsibility for preservation of microbial germplasm. Each maintains reference cultures of microbes, some from ATCC: or comparable collections, some fresh isolates from scientists working at or with the MIRCEN.

Molecular biology is increasingly becoming part of the MIRCENs' armory. The units facilitate access of research materials such as DNA sequences, gene probes, hybridomas and genetically engineered organisms. They also perform contract research and organize training in molecular biology.

\section{Centers}

MIRCENs serve as regional centers for technology transfer. They distributc on request-to academic, governmental and industrial laboratoriesthose cultures, techniques, and training relevant to food production, environmental management and commercial biotcchnology.

The MIRCEN network is not without its critics. Its scientific achievements are more practical than spectacular. That pragmatism is seen also in its geographical focus-the network is most active in the better developed of the developing nations. But as a mechanism for widespread international collaboration, the MIRCEN network can provide many lessons on the ways in which the international scientific community can assist less industrialized and disadvantaged national and regional economies $t o$ use microbiology and biotechnology.

For more information on the MIRCENs, contact Edgar Da Silva, UNESCO, Division of Basic Sciences, Paris 75015, France.

microbial biotechnology; economics of Ryarda speciosa as export crop; passion fruit research Rhizobium; field testing of Bradyrhizobium japonicus; soybean;

biotechnology; ethanol fermentation with Zymomonas mobilis; genetic manipulation of Saccharo myces cerevisiae; screening for lignocellulytic fungi, osmotolerant yeast,

biotechnology; diagnostics for Yersinia, Acinetobacter and Listeria in local food; carcinogenicity

Rhizobium; biological nitrogen fixation with Vigna unquiculata, Arachis hypognaea, and

fermentation, food and waste recycling; cassava bioethanol, cassava waste processing

biotechnology; algal biomass production; solid state fermentation of cassava and sago into feed; 